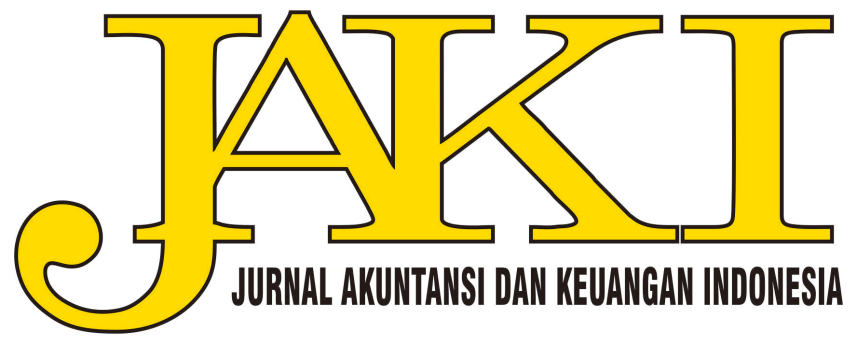

Volume 17

Issue 2 Volume 17, Issue 2, 2020

Article 5

$12-31-2020$

\title{
THE OBSTACLE FACTORS OF MUSHARAKAH AND MUDHARABAH APPLICATION IN PAKISTAN
}

\author{
Muhammad Arsalan Khan \\ Universitas Indonesia \\ Dodik Siswantoro \\ Universitas Indonesia \\ Abid Ur Rahman \\ Abdul Wali Khan University Mardan
}

Follow this and additional works at: https://scholarhub.ui.ac.id/jaki

Part of the Accounting Commons, Corporate Finance Commons, Finance and Financial Management Commons, and the Taxation Commons

\section{Recommended Citation}

Khan, Muhammad Arsalan; Siswantoro, Dodik; and Rahman, Abid Ur (2020) "THE OBSTACLE FACTORS OF MUSHARAKAH AND MUDHARABAH APPLICATION IN PAKISTAN," Jurnal Akuntansi dan Keuangan Indonesia: Vol. 17: Iss. 2, Article 5.

DOI: $10.21002 /$ jaki.2020.11

Available at: https://scholarhub.ui.ac.id/jaki/vol17/iss2/5

This Article is brought to you for free and open access by the Faculty of Economics \& Business at UI Scholars Hub. It has been accepted for inclusion in Jurnal Akuntansi dan Keuangan Indonesia by an authorized editor of UI Scholars Hub. 
Jurnal Akuntansi dan Keuangan Indonesia

Volume 17 Nomor 2, Desember 2020

\title{
THE OBSTACLE FACTORS OF MUSHARAKAH AND MUDHARABAH APPLICATION IN PAKISTAN
}

\author{
Muhammad Arsalan Khan \\ Postgraduate Department of Accounting, University of Indonesia \\ arsalan.pk91@gmail.com \\ Dodik Siswantoro \\ Department of Accounting, University of Indonesia \\ dodik.siswantoro@ui.ac.id
}

\begin{abstract}
Abid Ur Rahman
Institute of Business and Leadership (IBL), Abdul Wali Khan University Mardan

abid@awkum.edu.pk
\end{abstract}

\begin{abstract}
Islamic Banking is based on the Islamic financial system. It is a banking system whose fundamental rules and regulations are established on Shariah laws i.e., Islamic jurisprudence originated from the Quran and Sunnah of the Prophet Muhammad peace be upon him. Its functions must comply with Shariah rules and must not violate any Shariah principle. The Islamic finance system is based on Profit-loss sharing financing namely, Musharakah and Mudharabah but there are numerous issues and challenges faced by Islamic bank during the implementation of Musharakah and Mudharabah financing contracts. The various paper has been revealed some of the internal and external factors in this context, but the study is still unexplored in Pakistan. This paper aims to highlight those obstacles factors that affect the application of Musharakah and Mudharabah financing by Islamic Banks in Pakistan. This paper is based on the critical analysis of the related literature on the concepts of Profit-loss sharing based financing by Islamic Banks. The finding suggests 4 (four) main factors which hinder the application of Musharakah and Mudharabah by Islamic bank in Pakistan namely high risk, lack of awareness, Regulatory constraint and Low rate of return. Finally, this paper concludes by making recommendations that may be adopted by Islamic banks and regulators to facilitate the promotion of Musharakah and Mudharabah Financing.
\end{abstract}

Keywords: mudharabah, musharakah, profit-loss sharing, islamic banking, participatory financing.

\section{INTRODUCTION}

Islamic finance is based on the principles and mechanisms derived from the provisions of Islamic law. Their characteristics are composed of the exclusion of the interest rate, sharing of profits and losses, risk and uncertainty, asset-backed financing and so on. Islamic Banking is based on the Islamic fi- nancial system. It is a banking system whose fundamental rules and regulations are established on Shariah laws i.e., Islamic jurisprudence originated from the Quran and Sunnah of the Prophet Muhammad peace be upon him. Its functions must be in line with Shariah rules and must not violate any Shariah principle. Analyzing the conventional banking system, it is quite evident that 
the whole system is grounded on deposit creation and lending based on usury or interest. Whereas any kind of business activities based on interest are strictly prohibited in Islamic law and thus cannot be entertained by the Islamic banks at any level of their transactions. Therefore, we conclude that Islamic Banking is principally different from the modern conventional banking system.

In Islamic finance system is based on Profit-loss sharing namely, Musharakah and Mudharabah. Musharakah is contracts of partnership, where profits (or losses) are shared between the parties to the contract. While Mudharabah is a partnership between two parties provided that one party provide labor ('charity), while the second party provide property capital (mâl). There is an established belief that the essence of Islamic banking is participation should be according to risks and returns of investment projects and businesses by utilizing participatory Islamic financial contracts such as Musharakah and Mudharabah but also there is the obstacle which makes it hard to apply by an Islamic bank. In Pakistan, most of the Islamic financing contracts is not through profit-loss sharing contracts. Instead, Murabahah and Ijarah contracts are more preferred by customers. The current percentage of murabahah and ijarah application is 43 and 24 per cent of total Islamic financing contracts. While the rate of the application of Musharakah and Mudharabah is very low, that is only 2 and 3 per cent, respectively (Baele et al. 2014). Farooq and Ahmed (2013) mentioned in their study, most customer choose fixed return product by Islamic banks i.e., Murabahah, Ijara and diminishing Musharakah rather than Musharakah or Mudharabah because in Musharakah and Mudharabah he will have to share his actual profit with the bank. Fixed return product like Murabahah and Ijarah are in line with the Shariah principles and permissible to transact with these manners. However, these are not suggested methods of Islamic financing. Therefore, Islamic banks should keep an effort to finance customers on Musharakah and Mudarabah. Currently, the level of this effort is being made very low.

To Islamize Pakistan's economy Islamic ideology council was developed to introduce Islamic partnership companies. In this context, Mudharabah companies were established in Pakistan in 1984. The main purpose of Mudharabah companies in Pakistan is to engage in activities that will maximize ROI through the Shariah mode of financing for Certificate holders of the Mudharabah. These companies are purely compliant with Shariah law and providing Islamic financing contracts (e.g. Murabahah, Musharakah, Mudharabah, Ijarah, Istisna and Salam) by following the Mudharabah Companies and Mudharabah Rules that was set in 1981 under Section 41 of the said Ordinance, published in the Gazette of Pakistan, Extraordinary, Part I, dated 26-06-1980 and the Gazette of Pakistan, Extraordinary Part II, dated 26-01-1981 respectively (Rahman 1999). These regulations are set in according to shariah principles where there is a religious board that issue certificates to Mudharabah shall be a business which is in line with the injunctions of Islam and the Registrar shall not permit the floatation of a modaraba unless the Religious Board has certified in writing that the modaraba is not a business opposed to the injunctions of Islam.

At one stage the number of Mudharabah companies grew high as fiftytwo, but according to the Economic Survey (2019), the existing number of Mudharabah companies shrank to 38 . According to this survey on 29th Feb 2020, the total asset of Mudharabah companies shrank to 52.5 billion from 53.2 billion on March 31, 2019, Asghar and Afzal (2013) explained in their study one of the reasons that cause a reduction in the number of Mudharabah companies 
was that most of the Mudharabah companies failed at the initial stage to pay the cost raised of risk and to pay the wealth of the investors as compared to banks. Moreover, their result of performance was also lower than the average return of the Karachi Stock Exchange (KSE),

It is an undeniable fact that two vital alternates or substitutes to riba, Musharakah and Mudharabah have failed to attract Islamic Banks and Financial Institutions until the present time because, during 1980- 1985 under General Zia, President of Pakistan only few Musharakah and Mudharabah agreements between the Banks and the private parties could be finalized and that could only be done after the banks made certain relaxations in the original Draft Agreement of Musharakah and Mudharabah prepared by them (Rahman 1999). Even though the Islamic partnership contracts (Musharakah Mudharabah) fits perfectly into the Islamic finance system and Islamic economic scholars constantly encourage and support them, but Islamic banks and other financial institutions are reluctant to adopt these contracts as their main investment scheme.

Therefore, this research believes that it will be useful and interesting to point out those constraints in the application of Musharakah and Mudharabah by Islamic bank in Pakistan identified by various research studies in the discipline. Thus, our study follows the approach to answer the question 'what factors restrain Musharakah and Mudharabah financing by Islamic banks in Pakistan?' In line with this research, question aim to review literature about profit and loss financing system namely Musharakah and Mudharabah to identify the major obstacle factors that affect the application of shirkah Musharakah and shirkah Mudharabah financing by Islamic Banks in Pakistan

Thus, this article begins by briefly describing the profit-and-loss sharing system, followed by a detailed analysis of
Musharakah and Mudharabah. The article then concludes some obstacles that influences the low level of application of Musharakah and Mudharabah in Pakistan. Finally, this paper concludes by making recommendations that may be adopted by Islamic banks and regulators to facilitate the promotion of Musharakah and Mudharabah Financing.

\section{LITERATURE REVIEW}

Many researchers have given various clarifications to the less usage of Musharakah and Mudharabah financing. But still, the existing literature is varying, with diverse study concentrated on various issues related to the low level of Musharakah and Mudharabah by bank in Pakistan. Because of the difference in the literature, there is no one view understanding of the obstacles for implementing Musharakah and Mudharabah financing by the bank. The interest-based system is leading the economy to the path of crisis and affects the whole society. (Ahmad 2008). The aim of Islamic banking is not only profit maximization but to promote Islamic value and belief. Moreover, to guide society to invest in a better way to generate high profits (Farooq et al. 2010).

\section{The concept of Shirkah Mudharabah and Musharakah}

Shirkah is a contract of cooperation between two or more parties, which agrees to conduct a joint business operation for the sake of profit. profit \& loss sharing (PLS) involving two types namely Musharakah and Mudharabah. A Mudharabah course of action involves an association between the investor (s) (Rabb Al-Mal) and entrepreneur(s) (Mudarib). Where a one-party (investor) contributes to providing fund while the other party (Entrepreneur) utilizes fund and making a profit over the business (Abdouli 1991; Aggarwal and Yousef 2000). the profit 
is shared by both parties at the pre-agreed ratio, while in case of a loss the losses are solely borne by the investor (rabul ul mal) (Bacha 1997; ElGindi et al. 2009). In contrast, the other term Musharakah is a joint effort between two or more parties who equally contribute work (' charity) and property capital (mâl). And The provision of shirkah benefits of Musharakah must be based on a mutual agreement made by both parties while in case of loss in Musharakah all investor is borne loss to the extent of the ratio of their investment.

The profit-loss sharing system can trace back to the ancient form of financing practiced by Arabs since before the advent of Islam. Due to this ancient reason, scholars contemplate that profit-and-loss sharing financing is the actual and most promising form of Islamic contracts. Thus, Musharakah (equity partnership) and Modaraba (finance trusteeship) are two types of Islamic finance based on the profit-and-loss sharing system, where instead of lending money to an entrepreneur at a fixed rate of return, the financier shares in the venture's profits and losses (The Economist 2001).

\section{Partnership in Islamic banking Literature}

The partnership provides a base for Islamic banking (Algaoud and Lewis 2007). According to Gafoor (1995) the most punctual references to the redesign of banking framework based on partnership rather than interest can be found in the spearheading work by Qureshi (1996), Mahmud Ahmad, and Naiem Siddiqi in the late forties, followed by Abul A'ala Mawdudi in 1950.

Two pioneer Islamic economists namely Qureshi (1996) and Mahmud Ahmad proposed a financial system according to partnership (Shinsuke 2012). Qureshi (1996) in his book "Islam and the Theory of Interest" expressed that Riba (interest) is Haram (forbidden) in Islam yet sharikah (partnership) isn't. In Islam, there is no restriction on the bank if it becomes a partner with other business ventures and shares profit and loss rather than giving them an interestbased loan. His announcement infers that the organization based budgetary agreements, i.e, Musharakah and Mudharabah, are progressively fitting for the Islamic banking system (Shinsuke 2012). Mahmud Ahmad, at a similar time, expressed in his book about the partnership-based financial system. He mentioned that "the Shirakat banks would give money to industry and business based on Shirakat, that is, they would impart the profit to their account holders instead with a fixed rate of interest" (Ahmad 1947).

\section{The Primary Obstacle factors in the application of Musharakah and Mudharabah financing}

According to Al Haram (1990) Islamic banks find it difficult to identify sound financing opportunities. Moreover, the uncertainty of fraud, taxation system and extremely complex nature of equity financing is also creating a problem. In addition to that, it is Costly for the bank to employ specialists for financing on Musharakah basis. Some other reasons for the low level of usage of participatory namely, principal-agent conflict, moral hazard occurs due to information asymmetry (Chong and Liu 2009). Inline Iqbal and Llewellyn (2002) pointed out that asymmetric information is the most influential factor in the marginal application of Musharakah model which is the result of adverse selection and moral hazard problems. They also point out that the reduction of information asymmetry is a prerequisite for the implementation of an equity-based system. Khan (1995) mentioned that the results of prior studies show that the main factor in the low level of application of Musharakah is the moral hazard. He also concludes in his study that Profit-loss sharing instruments, which can allow profit retention 
by the user of funds and redeem consequently, could be more popular, particularly among risk-averse start-up firms.

According to Tajul Islam (2005), financing through profit and loss method is extremely riskier for banks in developing countries because of some reasons like (a) absence of proper accounting, (b) dishonesty, integrity, and investors character (c) a limited number of skillful entrepreneurs and (d) presence of contrary laws and regulations. MacMillan et al. (2008) provide several reasons why Islamic banking avoids profitloss sharing financing which are, difficulties in operation, entrepreneur's ethics, poor projects with high risk, absence of special regulatory framework, excessive monitoring cost, incapable procedures and inadequate expertise, unfair tax system and low rate of literacy. Khattak and Kashif-Ur-Rehman (2010) mentioned the level of satisfaction and customer's awareness about the products and services provide by Islamic banking in Pakistan and he found that people awareness toward some specific Islamic financial products was very limited such as Musharakah, Mudharabah, Murabaha, Ijara etc. Shariah corporate governance derived from Islamic banking and finance. Results suggest that every kind of business especially in Muslim countries must have in according to Shariah corporate governance to sustain in the longer term (Muneeza and Hassan 2011).

The main causes of the low level of application of Musharakah financing in the Islamic Banking Industry are namely, Unavailability of Guidelines/Regulations from the Central Bank, lack of government legal support, Lack of Interest of the Bank Management, lack of interest from the customers, lack of committed, Unavailability of Checks and Balances Mechanism of Musharakah Business, honest and skillful entrepreneurs, and Taxation Issues (Farooq and Ahmed 2013). Gafoor (1995) point out that some of the major issues related to the profit-loss sharing financing such as Investments under the profit \& loss sharing hold the capital for a significant period went with vulnerability and greater risk. Government participation in a project under profitloss sharing complicates the process of estimating a return rate on the funds borrowed. Government investment in an undertaking under participatory makes more difficult the process of assessing a return rate on the debt amount. Projects with long period provide low returns. An excessive number of and too frequent changes in the Government policies and absence of interest in the entrepreneurs to announce profits and to share it with the bank. Non-accessibility of appropriate and auspicious data from the entrepreneurs and lack of management and administration abilities in the entrepreneurs.

\section{METHODOLOGY}

\section{Research Design}

This study applies qualitative research with a descriptive analysis of the literature review. A literature review surveys books, scholarly articles, and any other sources relevant to a particular issue, area of research, or theory, and by so doing, provides a description, summary, and critical evaluation of these works concerning the research problem being investigated (Fink 2014). The literature used in this study is about the profit-loss sharing financing especially, Mudharabah and Musharakah contract in Islamic financial institutions to identify some primary factors which restrain its application by an Islamic bank in Pakistan. Researchers choose reputed articles to obtain the result of this study (See for example Chong and Liu 2009; Asghar and Afza 2013; Farooq and Ahmed 2013; Baele et al. 2014; Zafar and Nor 2019).

\section{Sample Selection}

For getting the relevant data researcher starts by searching in The Web of Science. The following keywords used to get 
the relevant data: participatory financing, Musharakah, Mudharabah, Islamic partnership, profit and loss sharing, and risk-sharing were identified using this database. Moreover, we used different databases like Elsevier (Science Direct), Wiley Online Library, Jstor, Springer Link, Taylor \& Francis, and Emerald etc. to search the above keywords. 1986 was considered as the initial year and the relevant literature published till 2019 were covered. Thus, the period of the selected studies is 1986 to 2019. Finally, we select the 40 most appropriate paper to answer the above question. Based on the analysis of these past articles we conclude with the factors in four main categories namely, high risk, lack of awareness, regulatory constraint, and low return.

\section{Data Analysis}

To analyze the data, we use systematic mapping study. Systematic mapping study is a systematic literature review method using predetermined stages, the selection of papers was also not carried out subjectively by the researcher but using the protocols and filters that had been determined in advance. Based on systematic mapping study we made four main classification from 40 most appropriate papers to get the result of this study. Each of these 4 classifications include some subfactors that effect the application of Musharakah and Musharabah financing by Islamic bank in Pakistan.

\section{RESULTS AND DISCUSSIONS}

By reviewing the above literature, we summarized the various obstacle factors affecting the application of Mudharabah and Musharakah financing by Islamic banks we conclude with four primary factors that restrain the application of Musharakah and Mudharabah by Islamic bank in Pakistan namely:

- High Risk

- Lack of Awareness
- Regulatory Constraint

- Low Return

\section{High Risk}

Musharakah and Mudharabah financings could be named high hazard speculations. These ideas of financing are hard to be executed because of their high likelihood of dissolution; because of different factors, for example, the entrepreneur's absence of skills and abilities to run a business. The idea of a joint business through profit-loss-sharing could make Islamic banks mindful in giving financing through the Musharakah and Mudharabah financing. The invested funds are generally claimed by investors who consistently anticipate that their cash should be secure. Islamic banks need to supplant the investor's cash if a misfortune happens. According to Farooq and Ahmed (2013), the future of business is uncertain that may earn a profit or incur losses, therefore participatory financing is riskier and the demand for participatory financing remain low by bank in Pakistan. He extended Musharakah And Mudharabah Financing need a lot of information about the entrepreneur's abilities and capabilities which may be hardly available, besides that lack of expertise, lack interest of the bank management, lack of commitment, lack of honesty and make these participatory finances riskier.

Based on financial stability review by the State Bank of Pakistan the major reason for the low-level application of partnership contract is agency problem and asymmetric information. Since Musharakah and Mudharabah contract is based on the paradigm of principal and agent hence the possibility of agency problem is too high. Agency problem occurs when there is an unequal of information, between the principal and the agent, which occur because of asymmetric information (Zafar and Nor 2019). Asymmetric information is a circumstance that emerges when lacking information on one party about 


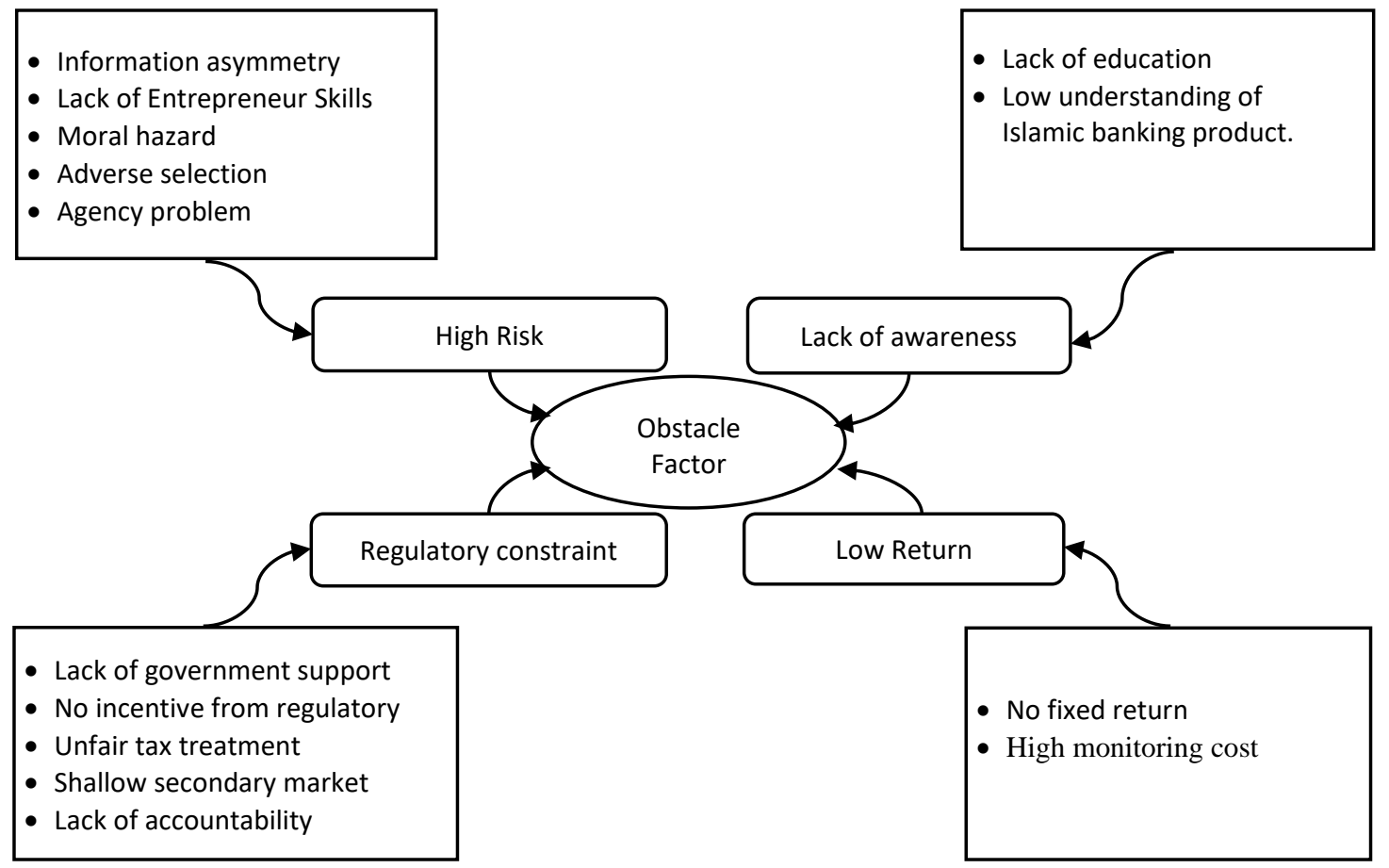

Figure 1: Major Obstacle factor in the application of Musharakah and Mudharabah

\section{by Islamic bank in Pakistan}

the other one engaged transaction makes it difficult to take precise decision while leading that transaction (Mishkin and Eakins 2011). Since partnership contracts are based on principal and agent agreement (Bashir 1996), these are inclined to the asymmetric information problem. The agent (the party who looks for the fund) being an insider party has better information about the project he/she wishes to participate in; whereas the principal (a bank which gives the financing expected to start the project) being an outsider party usually has limited information about potential returns and the related uncertainty of the project than an agent (Khalil et al. 2002). This symmetric information creates a high-risk participatory contract, for example before the project is started (adverse selection) and after it has begun (moral hazard).

Asymmetric information hurts participatory contracts which create an adverse selection and moral hazards (Zafar and Nor 2019). Adverse selection may come from before the project get started while hiding the information by an agent about his abilities to run the project and related uncertainties with it. While, the moral hazard comes after the project start, where the agent used firm resources and take some unnecessary risk for his interest and do not prefer the interest of the principal and the company value.

\section{Lack of awareness}

The most influencing factor that hinders the application of Profit-loss sharing financing is the lack of understanding about Islamic banking by general people. Knowledge about the Islamic banking system especially Mudharabah and Musharakah is still very lack in Muslim society and still, the majority of people think that Islamic banking is still almost the same as conventional banking. Lack of awareness lowers the demand for Islamic banking which hinder the low level of application of Musharakah and Mudharabah by Islamic bank in Pakistan.

The lack of proper education and awareness makes obliviousness and unreliability in our decisions. Islamic banking is 
Table 1

Awareness of Islamic Banking Contracts (In Percentage)

\begin{tabular}{lccc}
\hline Contracts & Corporate & Banked & Un-Banked \\
\hline Qardh-e-Hasana & 56 & 47 & 20 \\
Musharakah & 33 & 9 & 3 \\
Ijarah & 13 & 9 & 3 \\
Mudarabah & 15 & 10 & 2 \\
Murabahah & 7 & 4 & 1 \\
Istisnaa & 5 & 3 & 1 \\
Salam & 5 & 3 & 1 \\
Diminishing Musharakah & 4 & 3 & 1 \\
\hline
\end{tabular}

Source: Pakistan Islamic Finance Report 2016

facing the difficulty of being ignored in the Islamic finance industry. Individuals have distinctive perspective about Islamic banking, based on the opinion of few people Islamic bank is the same as the conventional bank, where some people say that there is no concept of Islamic banking and finance system.

Individuals don't think about their religious responsibility while going into the banking system. They are not very much aware of how unsafe riba is for the Muslim. As indicated by a Hadith of Prophet Muhammad peace be upon him exchanging with riba is a greater sin than eating pork. even though still many people ignore it. These difficulties are because of the absence of education about the Islamic banking system.

Advancing Islamic banking isn't just satisfying the religious commitment however useful for the economic growth of a country. Many of the Muslims as well as the nonMuslims country benefiting their economies by adopting the Riba free banking system. such as UAE, Saudi Arabia, Kuwait, Indonesia, Qatar, Kuwait, Bahrain, and Malaysia. These nations are completely profiting their economies from the Islamic banking system. Pakistan as a Muslim country should take some necessary steps to educate the people about Islamic banking to advance the Islamic financial system around the country. despite the fact, that in Pakistan literacy rate is low it not an easy task to educate the people easily but still, its education is the possible way to bring people to the Islamic banking system.

The below tabular data is taken from the Pakistan Islamic Finance Report 2016, which illustrate the percentage of the population in Pakistan who aware of the product provided by an Islamic bank in Pakistan. In the following table the awareness is divide into 3 categories (banked, unbanked and corporate). Banked is the population who interact with the bank directly by open accounts and already using the financial services provided by the bank. Where the unbanked population do not use any financial services provided by the bank. While corporate is the small and medium enterprises and other companies which are directly or indirectly connected with the bank. According to this survey, the understanding of both the banked and unbanked population concerning Islamic financial contracts is very low. But Among the banked businesses, there was a greater understanding of the range of Islamic financial contracts. For all these populations the most familiar concept was of qard-ehasana (charitable interest- and profit-free loans) and respondents unanimously believed that Islamic banks should offer this service.

According to the next table by the Pakistan, Islamic Finance Report 2016 shows the understanding of the basic concept of Islamic banking in Pakistan. The following tabular data shows that in Pakistan the 


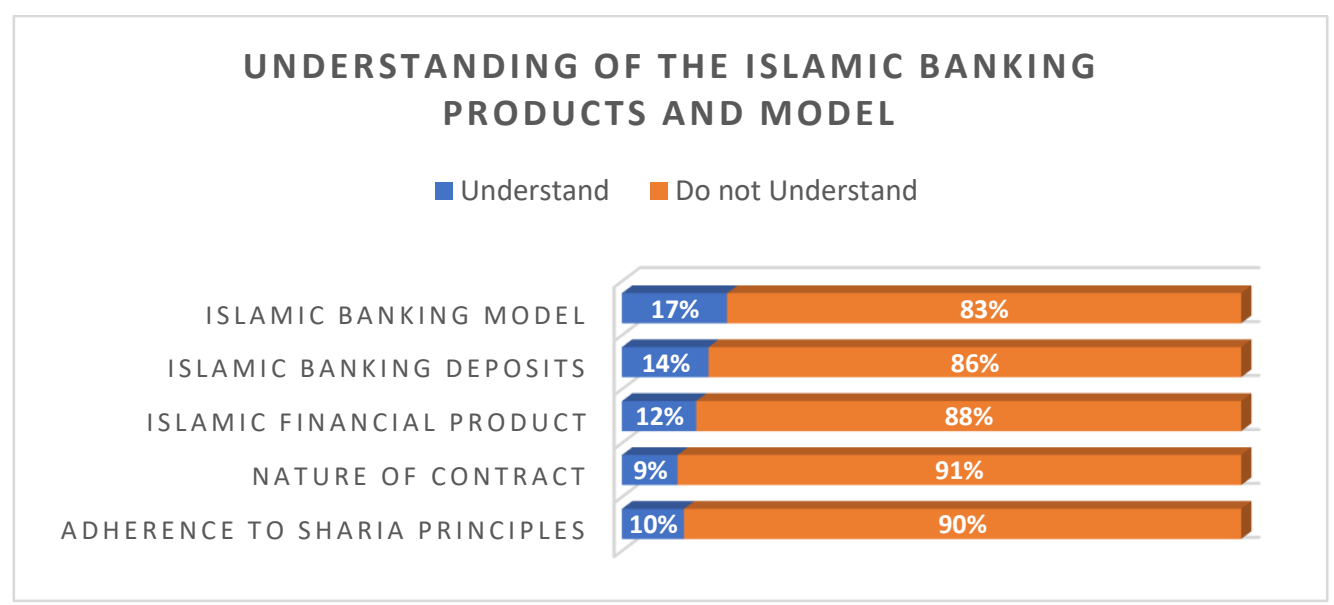

Source: Pakistan Islamic Finance Report 2016

Figure 2

\section{Understanding of the Islamic Banking Product and Model}

understanding of the basic concept of Islamic banking is very low.

Islamic bank can play a significant role in the economic growth of a country by growing 'their activities in each part of a country. These financial institutions should provide some awareness program across the country which help people to understand the concept of Islamic banking. The state should offer the syllabus where Islamic banking ought to be instructed in the school and colleges. Restriction of the Riba ought to be underlined in the prospectus which will bring awareness about Islamic banking from the basic schooling.

\section{Regulatory Constraint}

As per Yousef (2004) the legal and economic system supports the financial system around the world. These legal and economic systems depend on the regulatory, institutions political structures and legal and institutional factors, for example, bureaucratic quality, expropriation risk and corruption. For the effective regulation of Islamic financial institutions, a sound regulatory framework is essential (Wilson 2003), and the development of participatory financing (Haque and Mirakhor 1986). the basic component of the sound regulatory framework for Islamic banking includes the Security law, business law, Shariah law, insolvency law, property law, Taxation law. Civil law, common law, and employment law (Abdul Rahman et al. 2014).

The main regulatory obstacle factors include Lack of support from the regulator because there are no initiatives to facilitate regulation and institutional changes needed to support Islamic banking, there is no supporting institution to promote profit-loss sharing financing, and The Lack of uniform regulatory (Ascarya and Yumanita 2006). while Government and Other Institutions hindrance factors are namely, No supporting policy to promote participatory financing for public projects, Unfair tax treatment, which treats profit as taxable and interest as nontaxable, Secondary market for Islamic financial instrument is not available, so that limiting Islamic banks to allocate or access liquidity according to Shariah, Obscure ownership right, because profit and loss financing needs clear-cut and efficient ownership right and Lack of uniformity in the religious principles (Ascarya and Yumanita 2006).

In Participatory contracts, the unfair tax treatment is considered one of the major obstacles to applying Musharakah and 
Mudharabah by the bank. since there are Unfair tax treatment and government discrimination against profit-loss sharing contracts Islamic banks tend to adopt nonpartnership contracts. As Mutalip and Lutfi (2009) mentioned that less government support, in the form of tax exemptions and other incentives is considered a major obstacle factor in the application of Mudharabah and Musharakah contracts. This legal discrimination in profit-loss sharing and interest-based financing lead further issue like tax evasion, which makes participatory contracts less reliable tool for profit sharing. This argument is supported by the case of Mudharabah companies in Pakistan, as in Pakistan the tax-free status on Mudharabah companies was finished in 1992 and the growth of these companies was impressive until 1992 (Dar and Presley 2000)

According to Hooker (2013) In Pakistan Islamic Banks avoided participatory financing because there was a lack of credibility in the Pakistani government. There are little accountability and widespread corruption in the financial sector so Islamic banking was unwilling to use participatory financing as they would have trouble in observing their investment. There was also little demand for participatory financing from entrepreneurs because there was an extensive tax evasion which made the business community comfortable with manipulating tax returns however participatory financing demands accurate accounts so that two parties can get equal profit on their investment. Businesses were unwilling to share this information with the banks and the banks were hard to believe that businesses provided quality information (Akram 1994).

Even though in Pakistan there is already a regulatory framework such as the Mudharabah Rules 1981, Mudharabah companies and Mudharabah ordinance 1980, the State Bank of Pakistan's prudential regulations, and The Guidelines for Issuance of Musharakah Certificates for Mudharabah. But still needed the standardized participatory financing should be constructed in line with another Islamic country legal framework.

\section{Low Return}

One of the major obstacles in the lowlevel application of the Musharakah and Mudharabah contract is a low return on investment. Return on investment (ROI) is the profits earned on investment few expenses. The efficiency of a project can be measure through ROI. ROI for Musharakah and Mudharabah contracts is the profit earned by the business entity. Based on equity-based contracts, Musharakah and Mudharabah do not offer a fixed return on the investment. As Farooq and Ahmed (2013) mentioned in their study, the customer is reluctant to share the actual profit of his business which is higher than the Kibor rate with the bank and mostly customer chooses fixed return product by Islamic banks i.e., Murabaha, Ijara rather than Musharakah or Mudharabah because in Musharakah he will have to share his actual profit with the bank. This makes Participatory financing extremely risky and less attractive. Many investors avoid Musharakah and Mudharabah financing because conventional banks provide debt contracts with a fixed rate of return which protect investor capital (Rosly and Zaini 2008). Before making a Mudharabah or Musharakah contract investor must realize that these contracts offer no security on the investment and there is a possibility of loss and no return (Mirakhor and Zaidi 2007).

Another reason why Islamic banking is reluctant to apply Musharakah and Mudharabah is monitoring cost due to agency problem. Agency problem in Islamic partnership contracts arise from information asymmetry between the parties (principal and agent/manager) involved in the contract and 
furtherly it rises the higher monitoring cost (Bacha 1997; Jouaber and Mehri 2012). In the same issue Mirakhor and Zaidi (2007) mentioned in their paper, that agency cost lead to monitoring cost, which decreases the demand for Mudharabah contracts. to align the incentives of the principal and the managers, the mechanism called monitoring (Kuypers 2011). For minimizing agency problem, intensive monitoring required to check manager activities, information asymmetry and to avoid a moral hazard or adverse selection. Hence costly monitoring is required by Islamic participatory financing, it increases the overall cost of the project which impact negatively on the ROI of the project. The difficulties that occur in monitoring investment hinder Islamic banks and other institutions to use partnership contracts (Hooker 2013). Same as every Islamic country agency problem and asymmetric information is the significant challenge for Islamic banks in Pakistan during the application of participatory finance which may make these Islamic banks extensive monitoring. Extensive monetary may reduce agency cost, but it also increases monitoring cost.

\section{CONCLUSION}

Islamic banking system whose fundamental rules and regulations are established on Shariah laws. These banking systems are based on profit-loss sharing financing especially, Musharakah and Mudharabah, but at present most of the Islamic institutions rely on interest-based financing contracts because participatory contracts, Mudharabah and Musharakah have numerous numbers issues that prevent its application by an Islamic bank. Same as all, Muslim country Pakistan banking system also reluctant the use of participatory contract, Musharakah and Mudharabah due to some obstacles. Our study aims were to identify those obstacle factors through an in- depth review of the previous literature related to our study.

Our finding reveals 4 (four) main obstacles factor that hinders the Islamic banking institution in Pakistan to apply participatory contracts. Firstly, our study finds that mostly Islamic bank avoid Participatory contract because it is extremely riskier for banks due to various reasons like agency problem, information asymmetry, lack of entrepreneur skills, moral hazard and adverse selection. second, because of lack of awareness and less education, people have little understanding of Islamic banking product which decrease the demand for participatory financing contracts. In addition to that, our study points out a various regulatory constraint which prevents Islamic banking in Pakistan to adopt Musharakah and Mudharabah namely, lack of government support, no incentive from regulatory, unfair tax treatment, shallow secondary market, lack of accountability. lastly, the low rate of return is one of the obstacle factors in the low-level application of Musharakah and Mudharabah. As equity-based contracts, Musharakah and Mudharabah do not offer a fixed return on the investment which makes participatory financing extremely risky and less attractive. Another reason costly monitoring is required by Islamic participatory financing, it increases the overall cost of the project which negatively impact the return on investment.

The limitation of our study is that we followed the qualitative research method by using only secondary data about Islamic partnership contracts with academia's point of view, therefore, if future studies can investigate practitioners' perspective to get primary data, which will help them to identify these obstacle factors by statistical analysis and better understand the problems facing by an Islamic bank in Pakistan. Besides this limitation our study provides some implication as well, this research can 
contribute to Government, Mudharabah companies, entrepreneurs, and Islamic banking institutions in Pakistan to promote Islamic partnership contracts all over the country. Because partnership contracts are the authentic modes of the Islamic financial system and they should influence Islamic banks and institutions across the country.

The Government and Islamic Banking Authority should implement Islamic participatory contracts to optimize the benefits of participatory contract in the nationwide financial system. This is suggested that Islamic participatory financing should not only be the primary mode of financing in Islamic banks but the whole Islamic financial system and Islamic monetary system as well.

\section{REFERENCES}

Abdouli, A. H. (1991). Access to Finance and Collaterals: Islamic Versus Western Banking Journal of King Abdulaziz University: Islamic Economics, 3 (1), 5562.

Abdul-Rahman, A. et al. 2014. Failure and Potential of Profit-Loss Sharing Contracts: A Perspective of New Institutional, Economic (NIE) Theory. Pacific-Basin Finance Journal, 28, 136151.

Aggarwal, R. K., and T. Yousef. 2000. Islamic banks and investment financing. Journal of Money, Credit and Banking, 32(1), 93120.Ahmad, K. (2000). Islamic Finance and Banking: The challenge and prospects. Review of Islamic Economics, 9, 57-82.

Ahmad, M. 1947. Economics of Islam: A Comparative Study. Lahore: Muhammad Ashraf.

Ahmad, W. 2008. Islamic Banking in the United Kingdom: Opportunities and Challenges. Kingston Business School: Kingston University, London.
Akram. 1994. An Introduction to Islamic Economics. International Institute of Islamic Thought (IIIT).

Algaoud, L. M., and M. K. Lewis. 2007. Islamic critique of conventional financing. Handbook of Islamic Banking, 38.

Ascarya, A., and D. Yumanita. 2006. The Lack of Profit and Loss Sharing Financing in Indonesian Islamic Banks: Problems and Alternative Solutions.

Asghar, A., and T. Afza. 2013. The Efficiency of Modaraba and Leasing Companies in Pakistan. Middle East Journal of Scientific Research, 17 (3), 305-314.

Bacha, O. I. 1997. Adapting Mudarabah Financing to Contemporary Realities: A Proposed Financing Structure. The Journal of Accounting, Commerce \& Finance, 1 (1).

Baele. L., M. Farooq, and S. Ongena. 2014. Of Religion and Redemption: Evidence from Default on Islamic Loans. Journal of Banking and Finance, 44 (6), 141-159.

Bashir, A. H. M. 1996. Investment Under Profit-Sharing Contracts: The Adverse Selection Case. Managerial Finance, 22(5/6), 48-58.

Beng Soon Chong and Ming-Hua Liu. 2009. Islamic Banking: Interest-Free Or Interest-Based?. Pacific-Basin Finance Journal, 17, 125-144.

Cheltenham, UK. Northampton, MA, USA: Edward Elgar.Khan, T. 1996. Practices and Performance of Mudarabah Companies: A case study of Pakistan's Experience. Jeddah: Islamic Research and Training Institute, Islamic Development Bank, 37.

Dar, H. A., \& Presley, J. R. (2000). Lack of profit loss sharing in Islamic banking: management and control imbalances. International journal of Islamic financial services, 2(2), 3-18.

ElGindi, T., M. Said, and J. W. Salevurakis. 2009. Islamic Alternatives to Purely 
Capitalist Modes of Finance: A Study of Malaysian Banks from 1999 to 2006. Review Of Radical Political Economics, 41 (4), 516-538

Farooq, M., and M. M. Ahmed. 2013. Musharakah Financing: Experience of Pakistani Banks. World Applied Sciences Journal, 21 (2), 181-189.

Farooq, U. et.al. (2010). Profile Analysis of the Customers of Islamic Banking in Peshawar, Pukhtunkhwa. International Journal of Business and Management, 5 (11): 106-117.

Fink, A. 2019. Conducting Research Literature Reviews: from The Internet to Paper. Sage Publications.

Gafoor Abdul ALM. (1995) Interest-Free Banking. Berkanlaan 76, Netherlands: Appentec Publications,37-41.

Haque, N. U., and A. Mirakhor. 1986. Optimal Profit-Sharing Contracts And Investment In An Interest-Free Islamic Economy. International Monetary Fund Working Paper, WP/86/12.

Hooker, S. 2013. More than a Matter of Faith: The Factors that Shape Islamic Banking, Department of Political Science Carleton College Northfield,

Hooker, S. 2013. More than a matter of faith: The factors that Shape Islamic banking. Department of Political Science Carleton College Northfield, Minnesota.

Islam, T. 2005. Mechanics of Islamic banking. Islamic Banking: How Far Have We Gone

Iqbal, M., and D. T. Llewellyn. 2002. Islamic Banking and Finance: (New Perspectives on Profit-Sharing \& Risk), Edward Elgar, Cheltenham, UK, Northampton, MA, USA.

Jouaber, K., M. Mehri. 2012. Agency Problems in Venture Capital Contracts: Islamic Profit Sharing Ratio As A Screening Device. Available At SSRN:

http://ssrn.com/abstract=2181416 or http://dx.doi.org/10.2139/ssrn.2181416.
Khalil, A. F. A. A., C. Rickwood, and V. Murinde. 2002. Evidence On AgencyContractual Problems In Mudarabah Financing Operations By Islamic Banks. In M. Iqbal and D. T. Llewellyn (Eds.), Islamic Banking and Finance: New perspectives on profit-sharing and risk (57-92).

Khan, T. 1995. Demand For And Supply Of Mark-Up And Pls Funds In Islamic Banking: Some Alternative Explanations, IRTI, IDB, Jeddah, KSA.The Economist. 2001. Forced Devotion Series: Finance and Economics. February, 17, 76-77.

Khattak, N., and K. Rehman. 2010. Customer satisfaction and awareness of the Islamic banking system in Pakistan. African Journal of Business Management, 4, 662671.

Kuypers, A. 2011. How is Dealt with The Agency Problem and What is The Role of The Board of Directors In It? http://arno.uvt.nl/show.cgi?fid=129369.

MacMillan et. al. 2008. Development in Islamic Banking: The Case of Pakistan.

Shinsuke, N. 2012. A Critical Overview Of The History Of Islamic Economics: Formation, Transformation, And New Horizons. Asian And African Area Studies, 11(2), 114-136.

Mirakhor, A., and I. Zaidi. 2007. Profit-andLoss Sharing Contracts in Islamic Finance. In Hassan, M. K., \& Lewis, M. K. (Eds.), Handbook of Islamic Banking (49-63): Edward Elgar Publishing.

Mishkin, F. S., and S. G. Eakins. 2011. Financial Markets and Institutions (7 ed.). Prentice-Hall.

Muneeza, A., and R. Hassan. 2011. Legal Obstacles in Shari'ah Corporate Governance of Islamic Financial Institutions in Malaysia. Journal of King Abdulaziz University: Islamic Economics, 24(2). 
Mutalip, A., and A. Lutfi. 2009. Islamic Venture Capital and Private Equity: Legal Issues and Challenges. Global Financial Services and Islamic Banking, Azmi \& Associates.Pakistan Islamic Finance Report. 2016. Innovation at Asia's Crossroads

Qureshi, A. I. 1996. Islam And The Theory of Interest (1st ed.). Lahore, Pakistan: Muhammad Ashraf Publishers.

Rahman, T. 1999. Mudarabah and the Pakistan Perspective. Jeddah: Islamic Research and Training Institute-IDB.Rosly, S. A, \& Zaini, M. A. M. (2008). Risk-return analysis of Islamic banks' investment deposits and shareholders' fund. Managerial Finance, 34(10), 695-707.

Saad Abul Sattar Al-Haram. 1990. Islamic Finance: The Experience Of The Sudanese Islamic Bank In Partnership (Musharakah) Financing As A Tool For Rural Development Among Small Farmers In Sudan.

Wilson, R. 2003. Regulatory Challenges Posed by Islamic Capital Market Products and Services. University of Durham, UK: IOSCO task force on Islamic capital market. Centre for Middle Eastern and Islamic Studies.

Yousef, T. M. 2004. The Murabaha Syndrome in Islamic Finance: Laws, Institutions and Politics. In C. Henry \& R. Wilson (Eds.), The politics of Islamic finance. Edinburgh: Edinburgh University Press.

Zafar, S., and E. Nor. 2019. Determinants of ROI in Mudarabah \& Musharakah Contracts in Pakistan: An Appraisal. International Journal of Business and Society, 20 (3), 1112-1129. 